\title{
Processes that influence dissolved organic matter in the soil: a review
}

\author{
Maria Regina Gmach ${ }^{1}$, Maurício Roberto Cherubin ${ }^{1}$, Klaus Kaiser $^{2}{ }^{(0}$, Carlos Eduardo Pellegrino Cerri ${ }^{*}$ (i)
}

\author{
'Universidade de São Paulo/ESALQ, Depto. de Ciência do \\ Solo, Av. Pádua Dias, 11 - 13418-900 - Piracicaba, SP - \\ Brazil. \\ ${ }^{2}$ Martin Luther University Halle-Wittenberg, Universitätsplatz \\ 10 - 06120 - Halle (Saale) - Germany. \\ *Corresponding author <cepcerri@usp.br>
}

Edited by: Paulo Cesar Sentelhas

Received May 23, 2018

Accepted November 25, 2018

\begin{abstract}
In tropical regions, climate conditions favor fast decomposition of soil organic matter (SOM), releasing into the soil organic composts in solid, liquid, and gaseous forms with variable compositions. Dissolved organic matter (DOM), a complex mixture of thousands of organic compounds, is only a small fraction of the decomposition products; however, it is highly mobile and reactive to the soil. Therefore, DOM play a key role in soil aggregation (formation of organometallic complexes), energy source for microorganisms, as well as C storage, cycling, and provision of plant-available nutrients. DOM multifunctionality to sustain soil functions and important ecosystem services have raised global scientific interest in studies on DOM fractions. However, previous studies were conducted predominantly under temperate soil conditions in natural ecosystems. Therefore, there is paucity of information on tropical soil conditions under agricultural systems, where DOM turnover is intensified by management practices. This review synthesized information in the literature to identify and discuss the main sources, transformations, and future of DOM in soils. We also discussed the importance of this fraction in $\mathrm{C}$ cycling and other soil properties and processes, emphasizing agricultural systems in tropical soils. Gaps and opportunities were identified to guide future studies on DOM in tropical soils.

Keywords: Brazil, dissolved organic carbon, agricultural soils, tropical soils
\end{abstract}

\section{Introduction}

Dissolved organic matter (DOM) is one of the most active and mobile $\mathrm{C}$ pools and has an important role in global C cycling (Kalbitz et al., 2000). In addition, dissolved organic carbon (DOC) affects the soil negative electrical charges denitrification process, acid-basic reactions in the soil solution, retention and translocation of nutrients (cations), and immobilization of heavy metals and xenobiotics (Zech et al., 1997). Soil DOM can be derived from different sources (inputs), such as atmospheric $\mathrm{C}$ dissolved in rainfall, litter and crop residues, manure, root exudates, and decomposition of soil organic matter (SOM) (Figure 1). In the soil, DOM availability depends on its interactions with mineral components (e.g., clays, $\mathrm{Fe}$ and $\mathrm{Al}$ oxides) modulated by adsorption and desorption processes (Saidy et al., 2015). It also depends on SOM fractions (e.g., stabilized organic molecules and microbial biomass) by mineralization and immobilization processes (Figure 1). In addition, the intensity of these interactions changes according to soil inherent properties (Kaiser and Guggenberger, 2007), land use, and crop management (Saidy et al., 2015).

During the decomposition of organic material, most $\mathrm{C}$ is lost as $\mathrm{CO}_{2}$ to the atmosphere by microbial oxidation. Soil type and landscape slope, leaching, and runoff (Figure 1) are also important processes associated to DOM losses in the soil (Veum et al., 2009). In welldrained soils, leached DOC can reach the water table and release nutrients and pollutants that can contaminate groundwater (Thayalakumaran et al., 2015; Sparling et al., 2016), whereas runoff transports DOM and xenobiotics to other areas, rivers, and lakes.

Most studies have focused on understanding the soil DOM dynamics and its potential implications in water contamination in temperate forests and wetland areas; however, results from agricultural sites remain scarce in the literature (Van Gaelen et al., 2014), especially in tropical conditions.

Therefore, this literature review investigated discussions in previous studies on DOM and determined the current interest in this research topic in Brazil. For that purpose, we analyzed information in the literature to describe importance, source and production, transformation processes, and future of DOM in the soil-atmosphere system, emphasizing agricultural soils in tropical conditions. Finally, gaps and opportunities were delineated to guide further research for a better understanding of the importance and implications of DOM changes in tropical soils.

\section{Increase in scientific interest in DOC/DOM}

Since studies on soil DOC/DOM were introduced in the early 1980s, interest in this topic in aquatic and terrestrial systems has increased linearly. However, DOM studies in the soil systems, especially in agricultural soils are uncommon in Brazil. To illustrate this contrast between the number of publications on DOM/ DOC in Brazil and abroad, we performed a simplified bibliometric study in the Web of Science (WoS) database.

Initially, searching the terms "dissolved organic carbon" or "dissolved organic matter" as a "topic" from 1990 to 2017 provided 14,168 and 13,054 publications, respectively. For comparison purposes, only the topic "DOC" was used to avoid an overlap of results. When the word "soil" was added in the searches, the total number of publications decreased to 4,347 (Figure 2A) during the same period. When the searches were restricted to studies conducted in Brazil, the terms "DOC" and "Brazil" showed only 134 publications (Figure 2B), while search- 
ing for "DOC" and "USA", 593 publications were found for the same period. In addition, searching for "DOC" and "Europe" showed 265 publications and for "DOC" and "Germany", 217 publications were found, which is a large number for a relatively small country in territorial terms (23 times smaller than Brazil).

The number of publications decreased further when the word "soil" was added (i.e., "DOC" and "Brazil" and "soil"), resulting in 38 publications until 2017 (Figure 2C), but only 14 publications actually showed results from soil experiments (Table 1), and only a few had DOC fluxes as the main variables of study or evalu- ated DOM dynamics in the soil profile. Moreover, only one article evaluated DOC in the soil in Brazil recently (2018) (Table 1).

Complementary to this search in Web of Science database, the same search was performed in the Scopus and Scielo databases (i.e., databases that comprise scientific papers published in Brazilian and some Latino-American journals). The results found in the Scopus database are very similar to those found in the Web of Science. In the Scielo database, the aim was also to find publications in Portuguese; however, the addition of the terms "dissolved organic carbon" and "soil" showed only

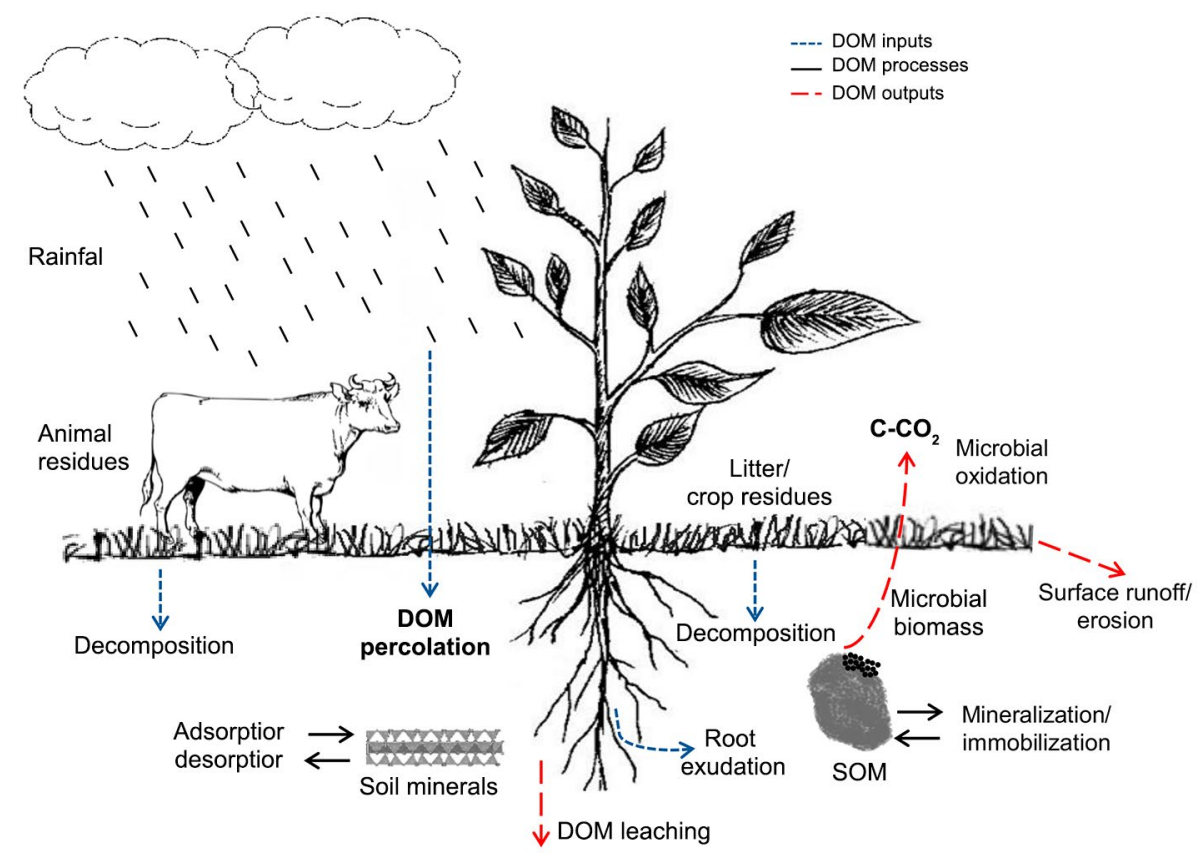

Figure 1 - Schematic representation of main inputs, transformation processes, and DOM losses in the soil system.
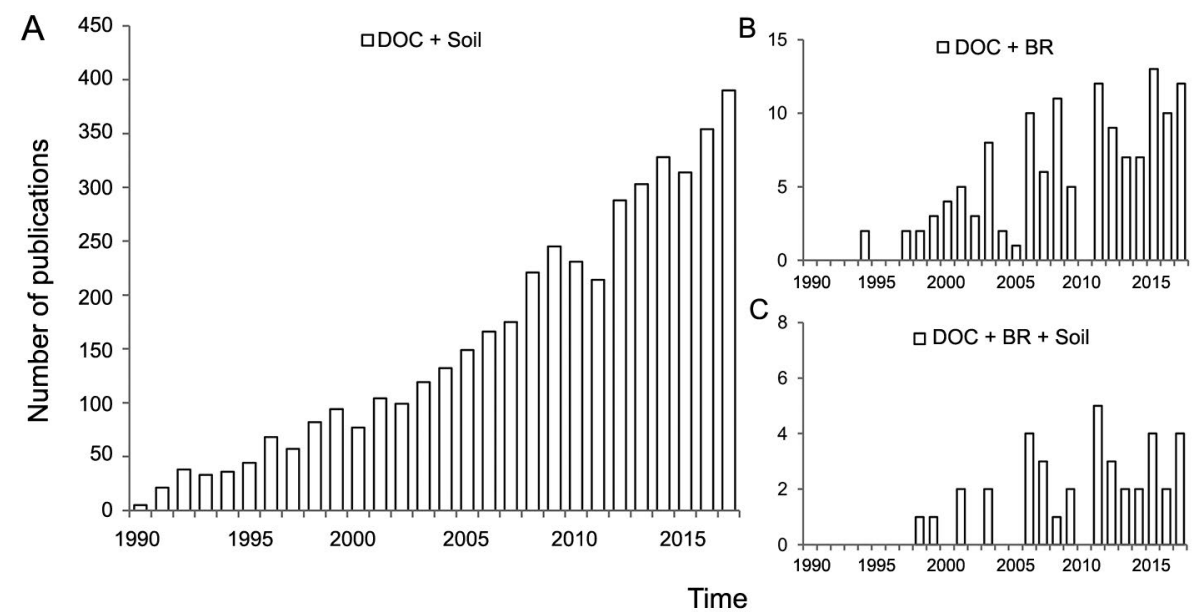

Figure 2 - Evolution in the number of publications of research on DOC in the Web of Science database. a) globally, and; b and c) in Brazil. DOC+Soil: "dissolved organic carbon" AND "soil"; DOC+BR: "dissolved organic carbon" AND "Brazil"; DOC+BR+Soil: "dissolved organic carbon" AND "Brazil" AND "soil". 


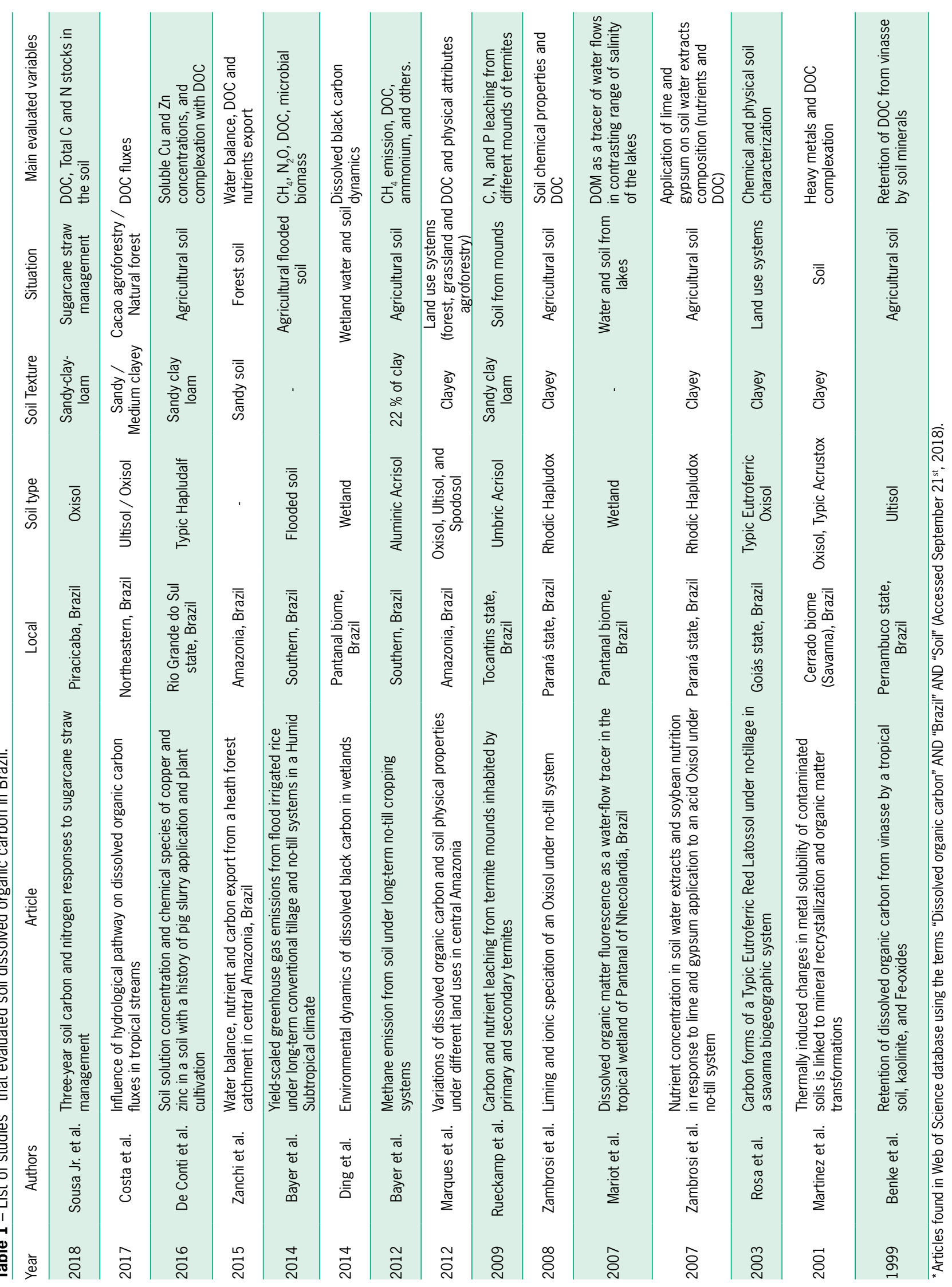


six publications. In addition, terms such as "soluble carbon," "crop," and "carbon leaching" were also searched jointly with DOC or DOM and Brazil, but there were few results.

These searches in the main scientific databases showed the lack of the studies in Brazil on this important $\mathrm{C}$ fraction. While the international scientific community is concerned with understanding DOM implications on the functioning of natural and anthropic ecosystems, in Brazil, there is much to advance to understand DOM dynamics, especially in agricultural systems with diversified management practices (e.g., no-till, cover crop, crop-livestock-forest integration, and green sugarcane harvesting).

\section{Definition and main sources of DOM}

Dissolved organic matter (DOM) is considered a complex mixture of thousands of organic compounds with diversified chemical compositions and properties (Catalá et al., 2015; Flerus et al., 2012; Thurman, 1985). However, a small proportion of DOM can be chemically identified, mostly as low molecular weight substances, such as organic acids, sugars, and amino acids (Herbert and Bertsch, 1995), hindering a thorough chemical definition of DOM (Silveira, 2005). DOM is a source of energy and organic nutrient forms, such as nitrogen $(\mathrm{N})$ and phosphorus $(\mathrm{P})$ readily accessible for soil microbiota (Burford and Bremner, 1975; McDowell et al., 2006). The origin, function, and future of these compounds in terrestrial ecosystems are only partially understood (Wang et al., 2016), as well as the factors that control soil DOM in the soil profile (Zhou et al., 2015). The DOC is a minor fraction of soil organic carbon (SOC), although DOC is one of the most mobile and bioavailable portions (Ghani et al., 2013; Marschner and Kalbitz, 2003). The decomposition of DOM can indicate processes that control SOM accumulation and stabilization (Kaiser and Kalbitz, 2012).

The main inputs of DOM into the soil are the rainfall, plant residues, root exudates, SOM, and microbial biomass (Kalbitz et al., 2000; Yano et al., 2005). DOM can be produced mainly by recent plant residues/litter and from relatively stable SOM decomposition (McDowell and Linkes, 1988; Michalzik et al., 2003). Some studies suggest that fresh $\mathrm{C}$ substrates are some of the most important DOM sources, such as plant residues, roots, and exudates, and their secretions including organic acids, phenols, sugars, and amino acids (Högberg and Högberg, 2002), (Wang et al., 2016). DOC originating from fresh leaf litter may contribute to the formation of an $\mathrm{A}$ horizon, whereas DOC originating from root litter may explain the presence of SOC at soil depths (Uselman et al., 2007).

In contrast, studies have shown that decomposition of stable SOM is the most important DOM source since wetter compounds predominate in DOM, suggesting that it originates from the large stock of native SOM than from recently added litter (Fröberg et al., 2003;
Zsolnay, 1996) depending on the organic material. Thus, part of DOM is derived from old SOM, indicating that the release of $\mathrm{C}$ from the plant into the soil solution is at a steady state with its decomposition or that litter and young SOM can be degraded by the microbiota without solubilizing first (De Troyer et al., 2011). Therefore, wet SOM and exchanges with aqueous phase may determine DOM chemical composition (Sanderman et al., 2008).

In general, recent litter and wet SOM constitute the most important DOM sources in soils (Kalbitz et al., 2000), varying in DOM concentration according to soil characteristics, soil use and tillage, and local climate. Thus, some compounds are specific to different functional soil or plant types, improving the capacity to use DOM as a soil quality indicator (Jones et al., 2014).

Furthermore, rainfall contributes to DOC content in the soil. A global study showed that $80 \%$ of $\mathrm{C}$ in rainfall is in the organic form (DOC), corresponding to 430 $\times 10^{12} \mathrm{~g} \mathrm{C} \mathrm{yr}^{-1}$, and $20 \%$ in the inorganic form (DIC), corresponding to $80 \times 10^{12} \mathrm{~g} \mathrm{C} \mathrm{yr}^{-1}$, totaling $510 \times 10^{12} \mathrm{~g}$ $\mathrm{C} \mathrm{yr}^{-1}$, from which $70 \%$ is deposited over land (Willey et al., 2000). These results show the importance of including rainfall into the global $\mathrm{C}$ balance. Besides containing $\mathrm{C}$, rainfall also contributes to the DOC movement and flux in the soil, and an increase in soil water flux may cause an increase in DOC content in soil solution (Chantigny, 2003).

\section{Factors associated with production and inputs of DOM in the soil}

The concentration of DOM in soil solution is controlled by several factors and processes, namely climate conditions, quantity and quality of the organic inputs, microbial activity (consumption and immobilization), soil texture, mineral adsorption, and leaching (Chantigny, 2003; Filep and Rékási, 2011; McDowell, 2003).

\section{Climate and soil type}

Climate characteristics can modify DOM production and release. Warm and humid weather conditions, such as the tropical climate, increase the microbial activity and the release of DOM from decomposing materials (Kalbitz and Knappe, 1997). Rainfall coming after dry periods may release a higher concentration of DOM into the soil solution than in normal rainy periods probably because of reduced decomposition rates in dry soils accumulate microbial products (Kalbitz et al., 2000). Rainfall intensity also may influence DOM sorption or leaching (Fröberg et al., 2007; Herbrich et al., 2017).

In general, high soil temperature and soil moisture were positively correlated to plant material decomposition rates, affecting directly DOM concentration in the surface soil layers (Zhou et al., 2015). Thus, DOC inputs and fluxes may be higher in tropical regions than in temperate regions.

Moreover, soil characteristics affect DOM inputs to the soil, such as clay content, water holding capacity, porosity and infiltration rates, and affect mainly the 
sorption force controlled by the concentration of clays and oxides in the soil (Saidy et al., 2013). The DOM concentration in the soil profile is a result of continuous sorption combined with microbial processing and subsequent desorption (Kaiser and Kalbitz, 2012). Aluminum (Al) and iron (Fe) oxides and hydroxides are some of the most important DOM adsorbents (Kaiser et al., 1996), especially in tropical soils.

\section{Quantity and quality of organic material}

The role and dynamics of DOM in soils are related to the quantity and quality of organic residues, which depend largely on their sources (Kalbitz et al., 2000; McDowell and Likens, 1988). The lignin content in residues regulates the litter decomposition rate and thus is important for DOM production (Guggenberger, 1994; Kalbitz et al., 2006). There is a strong relationship between DOC flux and soil C:N ratio (Aitkenhead and McDowell, 2000) in which decomposition of poor$\mathrm{N}$ materials seems to result in the production of more soluble compounds, explaining the positive correlation between C:N ratio and DOC concentration (Kalbitz and Knappe, 1997). When the C:N ratio is lower than 10, most $\mathrm{C}$ associated to SOM is consumed or re-assimilated by the soil microbiota to ensure that only a small portion of C remains in the soil as DOC (Kindler et al., 2011). Furthermore, a reduction of the $\mathrm{C}: \mathrm{N}$ ratio in the soil could lead to significant declines in DOC flux, especially in soils with lower initial mean soil $\mathrm{C}: \mathrm{N}$ ratio, such as grasslands, the savanna and others (Aitkenhead and McDowell, 2000).

Root exudates can also release different organic compounds, leading to intensive changes in the physical, biological, and chemical nature of soils (Jones et al., 2009). The dominant organic $C$ compounds in roots reflect the key compounds for cell metabolism, including sugars, amino acids, and organic acids (Kraffczyk et al., 1984).

\section{Soil use and management}

The labile DOC fraction is more sensitive to tillage disturbance than total SOC pool (Roper et al., 2010). Moreover, the use of DOM as an indicator for environmental changes and a tool for classifying ecosystems has been proposed in aquatic and marine sciences; consequently, using DOM in soil science seems desirable (Kaiser and Kalbitz, 2012). In the short-term, the relation between DOC and SOC concentration is not significant (Zhou et al., 2015), but the relationship is significant in the long-term perspective (Gregorich et al., 2000).

DOM production is sensitive to changes in land uses and management, such as the conversion of native forest into agriculture systems and the use of conventional tillage, that is, activities that can increase microbial activity (Van Gaelen et al., 2014). Higher microbial activity increases DOM release for a short period (Brye et al., 2001; Leinweber et al., 2008) and induces faster turnover of $\mathrm{C}$ fractions. In a study conducted in tropical soil from the Brazilian Amazon, DOC concentration was higher in an agroforestry system than in native forest and pasture (Marques et al., 2012). In addition, in the Brazilian savanna (Cerrado biome), Silva et al. (2007) found higher DOC flux in the soil under sugarcane crop than under eucalypt forest and native forest areas. Unfortunately, little has been done to quantify factors that affect DOM production in tropical conditions (Wang et al., 2016).

Residues amendment from the soil surface and the resulting release of easily biodegradable DOM by plant residues clearly induce microbial growth (De Troyer et al., 2011). Keeping crop residues on the soil surface is important to maintain $\mathrm{C}$ inputs and subsequently SOC (Cherubin et al., 2018). Thus, soils under no cover can suffer significant C losses as DOC forms (Baldock and Skjemstad, 2000; Sousa Jr. et al., 2018).

In summary, a defined chemical composition of DOM is difficult, and DOM origins are still little understood. To date, it is known that the main DOM sources are the plant residues/litter and stable SOM, which vary mainly according to the organic material. Thus, the production and release of DOM depend on a range of factors, such as soil characteristics (e.g., quantity of clays and oxides), climate conditions (e.g., temperature and humidity), characteristics of the plant residues (e.g., C:N ratio, lignin content, roots length), soil use, and management practices. This information shows that DOM production in the soil is higher in tropical conditions, under crop cultivation, and with plants with high C:N ratios and lignin content.

\section{Soil DOM changes and their implications for the biogeochemical cycle}

\section{Adsorption/desorption of DOM in soil}

Sorption processes of organic $\mathrm{C}$ on mineral surfaces contribute to accumulation and stabilization of SOC in the environment (Feng et al., 2005; Saidy et al., 2015). Free DOM movement is controlled mainly by its adsorption to soil clay surfaces (Ussiri and Johnson, 2004). The sorption of OC to mineral surfaces is strong and only partially reversible, with only a small portion extractable into fresh water, salt water, or organic solvents (Kahle et al., 2007; Kaiser and Guggenberger, 2007). Desorption varies according to the mineral and all DOC adsorbed by kaolinite is completely desorbed, while only 28 to $35 \%$ of adsorbed DOC is desorbed by Fe-oxides. These findings highlight the importance of goethite and hematite in DOM adsorption in tropical soils (Benke et al., 1999). Moreover, there is high correlation between DOM adsorption and specific surface area (SSA) of the clay fraction (Singh et al., 2016).

The biological stability of SOC sorbed to clay-oxide associations is influenced by the balance between the negative charge of clays and the positive charge of Fe-oxides (Saidy et al., 2015). Fe-oxides tend to be positively charged, especially in acids soils, and kaolinitic 
clays tend to carry less negative charges than other clays do (Saidy et al., 2013). In this sense, oxides can interact with both clay minerals and organic compounds to form organic-mineral associations that may influence significantly the size of the organic matter fraction resistant to biodegradation (Schneider et al., 2010).

Polyvalent cations usually reduce DOM leaching and increase DOM adsorption due to cation bridging and precipitation. Comparing cation adsorption, Singh et al. (2016) found that DOM adsorption was higher with increasing concentration of $\mathrm{Ca}^{2+}$ than of $\mathrm{Na}^{+}$. In contrast, anions, such as phosphate and sulfate, compete with DOM for adsorption sites, increasing DOM leaching (Kalbitz et al., 2000).

In general, soil with predominance of clays with high SSA, higher CEC, and especially high content of Fe/ $\mathrm{Al}$ oxides are more efficient to protect chemically and physically $\mathrm{C}$ of microbial mineralization and other loss processes (Kahle et al., 2003). Moreover, high concentration of oxides reduces DOM concentration in the soil solution, reducing losses by leaching. Thus, oxidic soils are expected to retain DOM more effectively.

\section{DOC effects on $C$ sequestration}

Soil organic carbon is the largest terrestrial SOM pool, containing about $1550 \mathrm{Pg}$ of $\mathrm{C}$, three-fold the amount found in the atmosphere or terrestrial vegetation (Lal, 2004). Therefore, the soil plays a key role in $\mathrm{C}$ sequestration, mitigating global warming and climate changes. For its characteristics, DOM is important in soil biogeochemical and is a crucial component of the net ecosystem C balance (Kindler et al., 2011). The DOM fraction is a potential source of stabilized $\mathrm{C}$, occurring in subsoil by $\mathrm{C}$ redistribution in deep layers (Fröberg et al., 2007; Kalbitz and Kaiser, 2008) leading to SOC accumulation (Schneider et al., 2010; Saidy et al., 2015), making it an important way to sequester $\mathrm{C}$ and decrease $\mathrm{C}$ loss in the $\mathrm{CO}_{2}$ form (Lal, 2004; Smith, 2004).

In long-term studies, De Troyer et al. (2011), Fröberg et al. (2003), and Hagedorn et al. (2004) found that OM from plant residues do not accumulate in the DOC pool; instead, it is mostly released as $\mathrm{CO}_{2}$. However, Uselman et al. (2007) found that during high rainfall and low temperatures, a larger fraction of ${ }^{14} \mathrm{C}$ from plant litter is lost as DOC, translocated or leached, than released as $\mathrm{CO}_{2}$, probably favoring more leaching than microbial metabolism. These results indicate that the proportion of $\mathrm{C}$ released as $\mathrm{CO}_{2}$ or as DOC is closely related with local climate characteristics.

Recently, Deng et al. (2017) showed that DOC leaching from the litter layer to topsoil in a subtropical forest was the major cause of rain-induced soil $\mathrm{CO}_{2}$ pulse; consequently, there is great concern with DOC contribution to increasing $\mathrm{CO}_{2}$ release in tropical soils, due to the increase in DOC fluxes by accelerated microbial activity. Nevertheless, correlations between DOC fluxes and $\mathrm{CO}_{2}$ release in tropical soils still need to be further investigated.

\section{Effects of DOM on soil properties}

The DOC is a sensitive fraction and can be considered an alternative tool to monitor adverse impacts on soil quality (Silveira, 2005). Due to its high mobility, the DOM movement is significant to the cycling and distribution of nutrients, such as $\mathrm{N}$ and $\mathrm{P}$ (Veum et al., 2009) and Fe and Al complexes (Fujii et al., 2009), in ecosystems.

Soluble organic acids that comprise DOM have functional groups, especially carboxylic and phenolic, which participate in many chemical reactions in the soil, such as organic metal complexation, increasing the ion adsorption rate and metal detoxification (Franchini et al., 2003; Roberts, 2006). These acids make exchangeable Al complex in the soil solution, making it nontoxic to plants (Amaral et al., 2004; Franchini et al., 1999). Therefore, in tropical soils, these organic acids can compete with other ions, such as phosphate ions, for adsorption sites, increasing $\mathrm{P}$ availability to plants (Andrade et al., 2003; Jones, 1998). The organic acids can also form stable organometallic complexes with $\mathrm{Fe}$ and $\mathrm{Al}$ in a wide $\mathrm{pH}$ range (Sposito, 1989). In addition, greater soil structural quality (e.g., higher aggregate stability, soil porosity, and water retention) is positively associated to DOM movement in the soil profile (Marques et al., 2012), since its movement and sorption are related to the water fluxes (Herbrich et al., 2017).

The metal detoxification activity depends on the DOM origin, since DOM originating from plant residues does not contribute significantly to the transport of organic pollutants and metals (Amery et al., 2007), because of this DOM is easily degradable and quickly decomposed rather than leached through deeper soil horizons. However, DOM derived from SOM can be used to predict the movement of both organic and inorganic pollutants in the soil (Amery et al., 2008).

The soil $\mathrm{pH}$ can affect DOM mobility; however, effects are still uncertain. Nonetheless, Tipping and Woof (1990) reported reduced adsorption capacity at high $\mathrm{pH}$ values with increase of DOM mobilization. Consequently, small increases in the soil $\mathrm{pH}$ lead to higher amounts of mobilized SOM.

In summary, DOM dynamics and processes are mainly affected by adsorption in the soil mineral phase and more strongly adsorbed by Fe and $\mathrm{Al}$ oxides, higher SSA clays, and polyvalent cations. Moreover, DOM is important in nutrient cycling and distribution in the profile, in phosphate availability, and in complexation of $\mathrm{Al}$, heavy metals, and pollutants. In subsoil, DOC is an important source of stabilized SOC and a potential C reservoir in deep soils, playing an important role in $\mathrm{C}$ cycling and sequestration in the soil. Therefore, in tropical conditions, DOM is possibly strongly adsorbed by $\mathrm{Fe}$ and $\mathrm{Al}$ oxides; however, fast production and changes of DOC can boost $\mathrm{CO}_{2}$ emission. Considering the direct and indirect influence and benefits of DOM on multiple soil chemical, physical, and biological properties, as well as the lack of information in tropical soils, this topic needs to be further explored in those conditions. 


\section{DOM output and losses}

Terrestrial hydrological pathways of $\mathrm{C}$ flow include rainfall, surface runoff, and drainage or leaching. The DOC fraction is more linked to leaching, while the particulate $\mathrm{C}$ fraction is more linked to superficial runoff (Edwards et al., 2008). Then, the process of DOM percolation from the soil surface transfers $\mathrm{C}$ and nutrients to deeper layers through soil solution (Fröberg et al., 2007). Thus, DOM can undergo sorption and be stored or transported to aquifers, moving from the terrestrial to the aquatic system (Sparling et al., 2016). Therefore, DOM leaching may be an important pathway of continuous soil $\mathrm{C}$ and nutrient losses (Kindler et al., 2011).

The main source of DOM leaching is SOM, because DOM from fresh plant residues is largely retained or consumed in topsoil, while only a small fraction is moved through the soil profiles (Fröberg et al., 2007, 2009). Some microorganisms can also contribute to DOM leaching, such as mycorrhizal symbionts that contribute to $\mathrm{C}$ flow, mainly through their structures, resulting in the release of exudates into the mycorrhizosphere (Jones et al., 2009).

Carbon losses by superficial runoff can be avoided with management for soil conservation. Continuous vegetal cover can provide a significant reduction in runoff, preventing potential contamination of waters by DOM (Veum et al., 2009). The DOC mobilization in runoff water results from antecedent soil moisture, as more DOC is released from drier soils (Van Gaelen et al., 2014). Then, the monitoring of $C$ losses by runoff and leaching to deeper layers is required in agricultural soils to estimate C balances (Nachimuthu and Hulugalle, 2016).

The DOM leaching is also controlled by the magnitude and direction of drainage water fluxes. During intensive and frequent rainfalls, elevated DOC concentration was found in groundwater from a sugarcane crop in Australia and was supplied via water flow (Thayalakumaran et al., 2015). Fast water movement, such as strong rains, might decrease DOM sorption in the soil, as well as microbial processing, resulting in fresh residues derived from DOM transported deeper into the soil (Fröberg et al., 2007). On the other hand, less time is available for SOM desorption, which may cause lower DOC concentration in the soil solution compared to a slower water percolation (Herbrich et al., 2017). Consequently, with more water volume in the soil, more DOM is probably derived from fresh residues than from SOM desorption.

The DOM leaching is considered a continuous form of $\mathrm{C}$ and nutrient losses from the soil and becomes a pollutant, as it reaches aquifers. In contrast, DOM may be a large reservoir of $\mathrm{C}$ in deep soils when it is adsorbed and stored in deep layers. Carbon losses by soil surface are generally linked to soil management system; however, $\mathrm{C}$ loss by leaching depends on many factors, such as soil characteristics, soil man- agement, and rainfall intensity. In the case of tropical conditions, where most areas contain deep soil, the DOM fraction may be labeled as an important reservoir of $\mathrm{C}$ at depth. To verify this hypothesis, further studies on DOM production and leaching should be carried out in tropical soils to estimate a complete C balance.

\section{Final remarks and perspectives}

The DOM concentration in soil solution is highly variable and depends on site-specific soil, climate, and land management conditions (Sparling et al., 2016). Most studies on DOM have been performed in temperate soils, predominating shallow soils. In contrast, little is known about tropical soils, which are highly weathered, deeper, and contain large amounts of $\mathrm{Al}$ and $\mathrm{Fe}$ oxides and hydroxides, leading to large adsorption.

The DOM fraction is an important active and bioavailable $\mathrm{C}$ source for microbial biomass, besides sequestering and storing $\mathrm{C}$ in deep layers. Despite its benefits, DOM dynamics has been preferentially evaluated in forests and peat soil, whereas only few studies have been conducted in agricultural soils (Wang et al., 2016). While land use and management practices affect directly the $\mathrm{C}$ fractions in the soil, there is little experimental data involving DOM mechanisms and processes.

Future studies are essential to determine the potential of best management practices (e.g., no-till, cover crop, crop rotation) to increase soil DOM, such as the removal of crop waste to feed animals or produce bioenergy can affect DOM dynamics in soils, and avoidance of DOM leaching in agricultural soils. Our research shows that little importance has been given to this topic in Brazilian agricultural soils, revealing a gap of information on DOM, which should be addressed in future studies.

\section{Acknowledgement}

MRG thanks the Coordenação de Aperfeiçoamento de Pessoal de Nível Superior (CAPES) for providing her PhD scholarship, and also thanks "Fundação Agrisus" for the financial support for the research visit in Germany. MRC thanks the "Fundação de Estudos Agrários Luiz de Queiroz" (Project \# 67555) for providing his postdoctoral fellowship. We would also like to thank the Banco Nacional de Desenvolvimento Econômico e Social (BNDES) and Raízen Energia S/A for funding our research (Project \#14.2.0773.1).

\section{Authors' Contributions}

Conceptualization: Gmach, M.R.; Cherubin, M.R.; Cerri, C.E.P. Data acquisition: Gmach, M.R. Writing and Editing: Gmach, M.R.; Cherubin, M.R.; Cerri, C.E.P.; Kaiser, K. 


\section{References}

Aitkenhead, J.A.; McDowell, W.H. 2000. Soil C: N ratio as a predictor of annual riverine DOC flux at local and global scales. Global Biogeochemical Cycles 14: 127-138.

Amaral, A.S.; Anghinoni, I.; Deschamps, F.C. 2004. Cover plant residues and mobility of dissolution products of surface applied lime. Revista Brasileira de Ciência do Solo. 28: 115-123 (in Portuguese, with abstract in English).

Amery, F.; Degryse, F.; Cheyns, K.; De Troyer, I.; Mertens, J.; Merckx, R.; Smolders, E. 2008. The UV-absorbance of dissolved organic matter predicts the fivefold variation in its affinity for mobilizing $\mathrm{Cu}$ in an agricultural soil horizon. European Journal of Soil Science 59: 1087-1095.

Amery, F; Degryse, F.; Degeling, W.; Smolders, E.; Merckx, R. 2007. The copper-mobilizing-potential of dissolved organic matter in soils varies 10-fold depending on soil incubation and extraction procedures. Environmental Science and Technology 41: 2277-2281.

Andrade, F.V.; Mendonça, E.S.; Alvarez, V.H.; Novais, R.F. 2003. Addition of organic and humic acids to Latosols and phosphate adsorption effects. Revista Brasileira de Ciência do Solo 27: 1003-1011 (in Portuguese, with abstract in English).

Baldock, J.A.; Skjemstad, J.O. 2000. Role of the soil matrix and minerals in protecting natural organic materials against biological attack. Organic Geochemistry 31: 697-710.

Benke, M.B.; Mermut, A.R.; Shariatmadara, H. 1999. Retention of dilssolved organic carbon from vinasse by a tropical soil, kaolinie and Fe-oxides. Geoderma 91: 47-63

Brye, K.R.; Norman, J.M.; Bundy, L.G.; Gower, S.T. 2001. Nitrogen and carbon leaching in agroecosystems and their role in denitrification potential. Journal of Environmental Quality 30: 58-70.

Burford, J.R.; Bremner, J.M. 1975. Relationships between the denitrification capacities of soils and total, water-soluble and readily decomposable soil organic matter. Soil Biology and Biochemistry 7: 389-394.

Catalá, T.S.; Reche; I.; Fuentes-Lema, A.; Romera-Castillo, C.; Nieto-Cid, M.; Ortega-Retuerta, E.; Calvo, E.; Álvarez, M.; Marrasé, C.; Stedmon, C.A.; Álvarez-Salgado, X.A. 2015. Turnover time of fluorescent dissolved organic matter in the dark global ocean. Nature Communications 6: 5986.

Chantigny, M.H. 2003. Dissolved and water-extractable organic matter in soils: a review on the influence of land use and management practices. Geoderma 113: 357-380.

Cherubin, M.R.; Oliveira, D.M.S.; Feigl, B.J.; Pimentel, L.G.; Lisboa, I.P.; Gmach, M.R.; Varanda, L.L.; Moraes, M.C.; Satiro, L.S.; Popin, G.V.; Paiva, S.R.; Santos, A.K.B.; Vasconcelos, A.L.S.; Melo, P.L.A.; Cerri, C.E.P.; Cerri, C.C. 2018. Crop residue harvest for bioenergy production and its implications on soil functioning and plant growth: a review. Scientia Agricola 75: 255-272.

De Troyer, I.; Amery, F.; Van Moorleghem, C.; Smolders, E.; Merckx, R. 2011. Tracing the source and fate of dissolved organic matter in soil after incorporation of a 13C labelled residue: a batch incubation study. Soil Biology and Biochemistry 43: 513-519.

Deng, Q.; Hui, D.; Chu, G.; Han, X.; Zhang, Q. 2017. Rain-induced changes in soil $\mathrm{CO}_{2}$ flux and microbial community composition in a tropical forest of China. Scientific Reports 7: 5539.
Edwards, A.C.; Kay, D.; McDonald, A.T.; Francis, C.; Watkins, J.; Wilkinson, J.R.; Wyer, M.D. 2008. Farmyards, an overlooked source for highly contaminated runoff. Journal of Environmental Management 87: 551-559.

Feng, X.; Simpson, A.J.; Simpson, M.J. 2005. Chemical and mineralogical controls on humic acid sorption to clay mineral surfaces. Organic Geochemistry 36: 1553-1566.

Filep, T.; Rékási, M. 2011. Factors controlling dissolved organic carbon (DOC), dissolved organic nitrogen (DON) and DOC/ DON ratio in arable soils based on a dataset from Hungary. Geoderma 162: 312-318.

Flerus, R.; Lechtenfeld, O.J.; Koch, B.P.; McCallister, S.L.; Schmitt-Kopplin, P.; Benner, R.; Kaiser, K.; Kattner, G. 2012. A molecular perspective on the ageing of marine dissolved organic matter. Biogeosciences 9: 1935-1955.

Franchini, J.C.; Hoffmann-Campo, C.B.; Torres, E.; Miyazawa, M.; Pavan, M. 2003. Organic composition of green manure during growth and its effect on cation mobilization in an acid oxisol. Communications in Soil Science and Plant Analysis 34: 2045-2058.

Franchini, J.C.; Miyazawa, M.; Pavan, M.A.; Malavolta, E. 1999. Dynamic of ions in acid soil leached with green manure residues extracts and pure solutions of organic acids. Pesquisa Agropecuária Brasileira 34: 2267-2276 (in Portuguese, with abstract in English).

Fröberg, M.; Berggren, D.; Bergkvist, B.; Bryant, C.; Knicker, H. 2003. Contributions of $\mathrm{Oi}, \mathrm{Oe}$ and $\mathrm{Oa}$ horizons to dissolved organic matter in forest floor leachates. Geoderma 113: 311322 .

Fröberg, M.; Hanson, P.J.; Trumbore, S.E.; Swanston, C.W.; Todd, D.E. 2009. Flux of carbon from 14C-enriched leaf litter throughout a forest soil mesocosm. Geoderma 149: 181-188.

Fröberg, M.; Jardine, P.M.; Hanson, P.J.; Swanston, C.W.; Todd, D.E.; Tarver, J.R.; Garten, C.T. 2007. Low dissolved organic carbon input from fresh litter to deep mineral soils. Soil Science Society of America Journal 71: 347.

Fujii, K.; Uemura, M.; Hayakawa, C.; Funakawa, S.; Kosaki, T.; Ohta, S. 2009. Fluxes of dissolved organic carbon in two tropical forest ecosystems of East Kalimantan, Indonesia. Geoderma 152: 127-136.

Ghani, A.; Sarathchandra, U.; Ledgard, S.; Dexter, M.; Lindsey, S. 2013. Microbial decomposition of leached or extracted dissolved organic carbon and nitrogen from pasture soils. Biology and Fertility of Soils 49: 747-755.

Gregorich, E.G.; Liang, B.C.; Drury, C.F.; Mackenzie, A.F.; McGill, W.B. 2000. Elucidation of the source and turnover of water soluble and microbial biomass carbon in agricultural soils. Soil Biology and Biochemistry 32: 581-587.

Guggenberger, G. 1994. Acidification effects on dissolved organic matter mobility in spruce forest ecosystems. Environmental International 20: 31-41.

Hagedorn, F.; Saurer, M.; Blaser, P. 2004. A 13C tracer study to identify the origin of dissolved organic carbon in forested mineral soils. European Journal of Soil Science 55: 91-100.

Herbert, B.E., and P.M. Bertsch. 1995. Characterization of dissolved and colloidal organic matter in soil solution: A review. p. 63-88. In McFee, W.W. and Kelly, M.J. ed. Carbon forms and function in forest soils. SSSA, Madison, WI, USA. 
Herbrich, M.; Gerke, H.H.; Bens, O.; Sommer, M. 2017. Water balance and leaching of dissolved organic and inorganic carbon of eroded Luvisols using high precision weighing lysimeters. Soil Tillage Research 165: 144-160.

Högberg, M.N.; Högberg, P. 2002. Extramatrical ectomycorrhizal mycelium contributes one-third of microbial biomass and produces, together with associated roots, half the dissolved organic carbon in a forest soil. New Phytologist 154: 791-795.

Jones, D.L. 1998. Organic acids in the rhizosphere: a critical review. Plant and Soil 205: 25-44.

Jones, D.L.; Nguyen, C.; Finlay, R.D. 2009. Carbon flow in the rhizosphere: carbon trading at the soil-root interface. Plant and Soil 321: 5-33.

Jones, D.L.; Simfukwe, P.; Hill, P.W.; Mills, R.T.E.; Emmett, B.A. 2014. Evaluation of dissolved organic carbon as a soil quality indicator in national monitoring schemes. PLoS One 9: e90882.

Kahle, M.; Kleber, M.; Jahn, R. 2003. Retention of dissolved organic matter by illitic soils and clay fractions: influence of mineral phase properties. Journal of Plant Nutrition and Soil Science 166: 737-741.

Kahle, M.; Kleber, M.; Jahn, R. 2007. Retention of dissolved organic matter by phyllosilicate and soil clay fractions in relation to mineral properties. Organic Geochemistry 35: 269-276.

Kaiser, K.; Guggenberger, G. 2007. Sorptive stabilization of organic matter by microporous goethite: sorption into small pores vs. surface complexation. European Journal of Soil Science 58: 45-59.

Kaiser, K.; Guggenberger, G.; Zech, W. 1996. Sorption of DOM and DOM fractions to forest soils. Geoderma 74: 281-303.

Kaiser, K.; Kalbitz, K. 2012 Cycling downwards: dissolved organic matter in soils. Soil Biology and Biochemistry 52: 29-32.

Kaiser, K.; Kaupenjohann, M.; Zech, W. 2001. Sorption of dissolved organic carbon in soils: effects of soil sample storage, soil-to-solution ratio, and temperature. Geoderma 99: 317-328.

Kalbitz, K.; Kaiser, K. 2008. Contribution of dissolved organic matter to carbon storage in forest mineral soils. Journal of Plant Nutrition and Soil Science 171: 52-60.

Kalbitz, K.; Kaiser, K.; Bargholz, J.; Dardenne, P. 2006. Lignin degradation controls the production of dissolved organic matter in decomposing foliar litter. European Journal of Soil Science 57: 504-516.

Kalbitz, K.; Knappe, S. 1997. Influence of soil properties on the release of dissolved organic matter (DOM) from the topsoil. Zeitschrift für Pflanzenernährung und Bodenkd 160: 475-483 (in German, with abstract in English).

Kalbitz, K.; Solinger, S.; Park, J.H.; Michalzik, B.; Matzner, E. 2000. Controls on the dynamics of dissolved organic matter in soils: a review. Soil Science 165: 277-304.

Kindler. R.; Siemens, J.; Kaiser, K.; Walmsley, D.C.; Bernhofer, C.; Buchmann, N.; Cellier, P.; Eugster, W.; Gleixner, G.; Grunwald, T.; Heim, A.; Ibrom, A.; Jones, S.K.; Jones, M.; Klumpp, K.; Kutsch, W.; Larsen, K.S.; Lehuger, S.; Loubet, B.; Mckenzie, R.; Moors, E.; Osborne, B.; Pilegaard, K.; Rebmann, C.; Saunders, M.; Schmidt, M.W.I.; Schrumpf, M.; Seyfferth, J.; Skiba, U.; Soussana, J.F.; Sutton, M.A.; Tefs, C.; Vowinckel, B.; Zeeman, M.J.; Kaupenjohann, M. 2011. Dissolved carbon leaching from soil is a crucial component of the net ecosystem carbon balance. Global Change Biology 17: 1167-1185.
Kraffczyk, I.; Trolldenier, G.; Beringer, H. 1984. Soluble root exudates of maize: influence of potassium supply and rhizosphere microorganisms. Soil Biology and Biochemistry 16: $315-322$.

Lal, R. 2004. Soil carbon sequestration impacts on global climate change and food security. Advanced Science 304: 1623-1627.

Leinweber, P.; Jandl, G.; Baum, C.; Eckhardt, K.U.; Kandeler, E. 2008. Stability and composition of soil organic matter control respiration and soil enzyme activities. Soil Biology and Biochemistry 40: 1496-1505.

Marques, J.D.O.; Luizão, F.J.; Teixeira, W.G.; Ferreira, S.J.F. 2012. Variations of dissolved organic carbon and soil physical properties under different land uses in Central Amazônia. Revista Brasileira de Ciência do Solo 36: 611-622 (in Portuguese, with abstract in English).

Marschner, B.; Kalbitz, K. 2003. Controls of bioavailability and biodegradability of dissolved organic matter in soils. Geoderma 113: 211-235.

McDowell, W.H. 2003. Dissolved organic matter in soils: future directions and unanswered questions. Geoderma 113: 179-186.

McDowell, W.H.; Likens, G.E. 1988. Origin, Composition, and flux of dissolved organic carbon in the Hubbard Brook Valley. Ecological Society of America 58: 177-195.

McDowell, W.H.; Zsolnay, A.; Aitkenhead-Peterson, J.A.; Gregorich, E.G.; Jones, D.L.; Jodemann, D.; Kalbitz, K.; Marschner, B.; Schwesig, D. 2006. A comparison of methods to determine the biodegradable dissolved organic carbon from different terrestrial sources. Soil Biology and Biochemistry 38: 1933-1942.

Michalzik, B.; Tipping, E.; Mulder, J.; Gallardo-Lancho, J.F.; Matzner, E.; Bryant, C.L.; Clarke, N.; Lofts, S.; Vicente-Esteban, M. 2003. Modelling the production and transport of dissolved organic carbon in forest soils. Biogeochemistry 66: 241-264.

Nachimuthu, G.; Hulugalle, N. 2016. On-farm gains and losses of soil organic carbon in terrestrial hydrological pathways: a review of empirical research. International Soil and Water Conservation Research 4: 245-259.

Roberts, S.K. 2006. Plasma membrane anion channels in higher plants and their putative functions in roots. New Phytologist 169: 647-666.

Roper, M.M.; Gupta, V.; Murphy, D. 2010. Tillage practices altered labile soil organic carbon and microbial function without affecting crop yields. Australian Journal of Soil Research 48: 274-285.

Saidy, A.R.; Smernik, R.J.; Baldock, J.A.; Kaiser, K.; Sanderman, J. 2013. The sorption of organic carbon onto differing clay minerals in the presence and absence of hydrous iron oxide. Geoderma 209-210: 15-21.

Saidy, A.R.; Smernik, R.J.; Baldock, J.A.; Kaiser, K.; Sanderman, J. 2015. Microbial degradation of organic carbon sorbed to phyllosilicate clays with and without hydrous iron oxide coating. European Journal of Soil Science 66: 83-94.

Sanderman, J.; Baldock, J.A.; Amundson, R. 2008. Dissolved organic carbon chemistry and dynamics in contrasting forest and grassland soils. Biogeochemistry 89: 181-198.

Schneider, M.P.W.; Scheel, T.; Mikutta, R.; van Hees, P.; Kaiser, K.; Kalbitz, K. 2010. Sorptive stabilization of organic matter by amorphous Al hydroxide. Geochimica et Cosmochimica Acta 74: 1606-1619. 
Silva, D.M.L.; Ometto, J.P.H.B.; Lobo, G.A; Lima, W.D.P.; Scaranello, M.A.; Mazzi, E.; Rocha, H.R. 2007. Can land use changes alter carbon, nitrogen and major ion transport in subtropical brazilian streams? Scientia Agricola 64: 317-324.

Silveira, M.L.A. 2005. Dissolved organic carbon and bioavailability of $\mathrm{N}$ and $\mathrm{P}$ as indicators of soil quality. Scientia Agricola 62: 502-508.

Singh, M.; Sarkar, B.; Biswas, B.; Churchman, J.; Bolan, N.S. 2016. Adsorption-desorption behavior of dissolved organic carbon by soil clay fractions of varying mineralogy. Geoderma 280: 47-56.

Smith, P. 2004. Soils as carbon sinks: the global context. Soil Use and Management 20: 212-218.

Sousa Junior, J.G.A.; Cherubin, M.R.; Oliveira, B.G.; Cerri, C.E.P.; Cerri, C.C.; Feigl, B.J. 2018. Three-year soil carbon and nitrogen responses to sugarcane straw management. BioEnergy Research 11: 249-261.

Sparling, G.; Chibnall, E.; Pronger, J.; Rutledge, S.; Wall, A.; Campbell, D.; Schipper, L. 2016. Estimates of annual leaching losses of dissolved organic carbon from pastures on Allophanic soils grazed by dairy cattle, Waikato, New Zealand. New Zealand Journal of Agricultural Research 59: 32-49.

Sposito, G. 1989. The Chemistry of Soils. Oxford University Press, New York, NY, USA.

Thayalakumaran, T.; Lenahan, M.J.; Bristow, K.L. 2015. Dissolved organic carbon in groundwater overlain by irrigated sugarcane. Groundwater 53: 525-530.

Thurman, E.M. 1985. Organic Geochemistry of Natural Waters. Nijhoff, Dordrecht, The Netherlands.

Tipping, E.; Woof, C. 1990. Humic substances in acid organic soils: modelling their release to the soil solution in terms of humic charge. Journal of Soil Science 41: 573-586.

Uselman, S.M.; Qualls, R.G.; Lilienfein, J. 2007. Contribution of root vs. leaf litter to dissolved organic carbon leaching through soil. Soil Science Society of America Journal 71: 1555.
Ussiri, D.A.N.; Johnson, C.E. 2004. Sorption of organic carbon fractions by spodosol mineral horizons. Soil Science Society of America Journal 68: 253.

Van Gaelen, N.; Verschoren, V.; Clymans, W.; Poesen, J.; Govers, G.; Vanderborght, J.; Diels, J. 2014. Controls on dissolved organic carbon export through surface runoff from loamy agricultural soils. Geoderma 226-227: 387-396.

Veum, K.S.; Goyne, K.W.; Motavalli, P.P.; Udawatta, R.P. 2009. Runoff and dissolved organic carbon loss from a pairedwatershed study of three adjacent agricultural Watersheds. Agriculture, Ecosystems \& Environment 130: 115-122.

Wang, X.; Li, C.; Luo, Y.; Hua, K.; Chou, M. 2016. The impact of nitrogen amendment and crop growth on dissolved organic carbon in soil solution. Journal of Mountain Science 13: 95103.

Willey, D.; Kieber, R.J.; Eyman, M.S.; Brooks, G.A. 2000. Rainwater dissolved organic carbon: concentrations and gloal flux. Global Biogeochemical Cycles 14: 139-148.

Yano, Y.; Lajtha, K.; Sollins, P.; Caldwell, B.A. 2005. Chemistry and dynamics of dissolved organic matter in a temperate coniferous forest on andic soils: effects of litter quality. Ecosystems 8: 286-300.

Zech, W.; Senesi, N.; Guggenberger, G.; Kaiser, K.; Lehmann, J.; Miano, T.M.; Miltner, A.; Schroth, G. 1997. Factors controlling humification and mineralization of soil organic matter in the tropics. Geoderma 79: 117-161.

Zhou, W.J.; Sha, L.Q.; Schaefer, D.A.; Zhang, Y.P.; Song, Q.H.; Tan, Z.H.; Deng, Y.; Deng, X.B.; Guan, H.L. 2015. Direct effects of litter decomposition on soil dissolved organic carbon and nitrogen in a tropical rainforest. Soil Biology and Biochemistry 81: 255-258.

Zsolnay, A. 1996. Dissolved humus in soil waters. p. 171-223. In: Piccolo, A., ed. Humic substances in terrestrial ecosystems. Elsevier, Amsterdam, The Netherlands. 